\title{
ANTIBACTERIAL ACTIVITY AND HUMAN CELL CYTOTOXIC OF COBALT (III) COMPLEXES WITH 1,10-PHENANTHROLINE AND CARBOHYDRATE LIGANDS
}

\author{
JOSÉ PARADA ${ }^{1^{*}}$, ANA MARÍA ATRIA ${ }^{1}$, RICARDO BAGGIO ${ }^{2}$, GUILLERMO WIESE ${ }^{3}$, SEBASTIÁN LAGOS ${ }^{3}$, \\ ALEQUIS PAVÓN $N^{3}$ ELIZABETH RIVAS ${ }^{3}$, LAURA NAVARRO 3 , GINO CORSINI
}

${ }^{1}$ Departamento de Química Inorgánica y Analítica, Facultad de Ciencias Químicas y Farmacéuticas, Universidad de Chile, Casilla 233, Santiago, Chile.
${ }^{2}$ Gerencia de Investigación y Aplicaciones, Centro Atómico Constituyentes, Comisión de Energía Atómica, Buenos Aires, Argentina.
${ }^{3}$ Laboratorio de Bacteriología Molecular, Instituto de Ciencias Biomédicas, Facultad de Ciencias de la Salud, Universidad Autónoma de Chile. Santiago, Chile.

\section{ABSTRACT}

The mononuclear cobalt (III) complex derived from 1,10-phenanthroline with lactose $\left[\mathrm{Co}(\mathrm{phen})_{2}\right.$ lactose $] \mathrm{Cl}_{2} \cdot 3 \mathrm{H}_{2} \mathrm{O}(\mathbf{1})$ has been prepared and its properties have been compared with the sucrose complex $\left[\mathrm{Co}(\text { phen })_{2}\right.$ sucrose $] \mathrm{Cl}_{2} \cdot 3 \mathrm{H}_{2} \mathrm{O}(2)$ and the complex without carbohydrate $\left[\mathrm{Co}(\mathrm{phen})_{2} \mathrm{Cl}{ }_{2}\right] \mathrm{Cl} \cdot 3 \mathrm{H}_{2} \mathrm{O}(3)$.

The chemical structure of (1) was assigned by ${ }^{1} \mathrm{H}-\mathrm{NMR}, \mathrm{IR}, \mathrm{CD}$ and UV-Vis spectral data. The antibacterial activity of (1) - (3) was evaluated by disc-diffusion assays, using Gram-negative and positive bacteria. The minimum inhibitory concentration of the three complexes on the studied bacteria and their cytotoxicity on HEK293 human cells was determined. A colorimetric plate assay was used to distinguish bacteriostatic from bactericidal effect. Finally, the complexes uptake mechanism was evaluated using bacteria with mutated genes that encode for carbohydrate and siderophore receptors. The results indicate that complex (1) has an antibacterial activity similar to (3), while (2) presents a more restricted one. Moreover, all three complexes act by a bacteriostatic effect against bacterial cells and both (1) and (3) use a siderophore uptake mechanism to enter on bacterial cytoplasm. Cytotoxicity assays show that carbohydrate complexes are not cytotoxic to human cells, in contrast with complex (3), which is highly toxic. These results suggest that the use of the lactose ligand would maintain the antibacterial activity and uptake mechanism of the complex at reasonable levels, and would also reduce its toxicity against human cells. Thus, its strategic use would allow a decrease in toxicity of complexes used in eventual studies on eukaryotic systems.

Keywords: Phenanthroline, Cobalt, complexes, Carbohydrate, antibacterial, cytotoxicity.

\section{INTRODUCTION}

Transition metals and their complexes are of current interest from several point of view, including their use as antimicrobial, antifungal, anticancer, antioxidant, an anti-inflammatory agent, etc. [1-4]. A wide variety of transition metal complexes, including $\mathrm{Ag}, \mathrm{Au}, \mathrm{Cu}, \mathrm{Co}, \mathrm{Fe}, \mathrm{Ir}, \mathrm{Pt}$, Rh and different ligands, have shown antimicrobial properties [5-14]. The biological activity of these compounds is highly dependent on the nature of the metal ions as well as the donor sequence of the intervening ligands (different ligands exhibiting different biological properties [15]).

Regarding this, 1,10-phenanthroline and its derivatives have been extensively used to obtain a diversity of complexes which display a broad range of biological activities, finding application as antitumor, antibacterial and antiviral agents [16-25].

On the other hand, cobalt is one of the most important trace elements for most animal species and humans [26]. Cobalt in inorganic form is a micronutrient for bacteria, algae, and fungi [27]. This element is found on vitamin B12, a coenzyme that plays an important role in various metabolic functions, including the ability to convert proteins, carbohydrates, and fats into energy [28, 29].

Reports on antibacterial properties of cobalt complexes have demonstrated that their antibacterial activity is usually enhanced as compared to that of the free ligand [30]. This seems to be the result of the increasing lipophilicity of the metal upon ligand coordination, which subsequently promotes the permeation through lipid bilayers of the cell membrane, thus blocking the metal-binding sites on the enzymes of microorganisms [31-33].

Considering the increase of bacterial diseases, the synthesis of compounds that prevent bacterial growth, and have a low cytotoxicity is of great interest. In this context, our research group has focused their attention on the synthesis of transition metal mixed complexes that present antimicrobial activity.

In this paper, we report the synthesis of the mononuclear complex $\left[\mathrm{Co}(\text { phen) })_{2}\right.$ lactose $] \mathrm{Cl}_{2} \cdot 3 \mathrm{H}_{2} \mathrm{O}(\mathbf{1})$, the evaluation of its antibacterial activity on Gram-negative and positive bacteria, and the cytotoxicity on normal human cells HEK293. The activity is compared to the one presented by mononuclear complexes $[\mathrm{Co} \text { (phen) })_{2}$ sucrose $] \mathrm{Cl}_{2} \cdot 3 \mathrm{H}_{2} \mathrm{O}(2)$ and $\left[\mathrm{Co}(\text { phen })_{2} \mathrm{Cl}_{2}\right] \mathrm{Cl} \cdot 3 \mathrm{H}_{2} \mathrm{O}(3)$ previously synthesized. In addition, the action mechanisms and uptake routes of the three complexes have been explored.

\section{EXPERIMENTAL SECTION}

2.1. Materials and instruments
All reagents and solvents employed were commercially available and used as received, without further purification.

The cobalt content of the complexes in the solutions, as in the solid compounds was determined by atomic absorption spectroscopy with a Perkin Elmer 1100B spectrophotometer. Absorption spectra were recorded on a Unicam UV3 spectrometer instrument. The circular dichroism (CD) spectra were monitored in a Yobin-Yvon CD 6 spectrometer. Elemental analyses were performed on CE Instruments EA 1108 elemental analyzer.

The infrared spectrum (4000- $600 \mathrm{~cm}^{-1}$ ) was recorded using a $\mathrm{KBr}$ pellet on a Perkin Elmer FT-IR C 97945 IR spectrometer. ${ }^{1} \mathrm{H}-\mathrm{NMR}$ measurements were performed in a DMSO solution with a Bruker DXR 300 spectrometer (300MHz).

\subsection{Synthesis of the complexes}

Complex (1) was prepared using the method reported by Parada et al. for the preparation of $\left[\mathrm{Co}(\mathrm{phen})_{2} \mathrm{~L}\right]^{2+}(\mathrm{L}=$ sucrose $)(\mathbf{2})$. An aqueous solution of $\left.[\mathrm{Co} \text { (phen })_{2} \mathrm{Cl}_{2}\right] \mathrm{Cl}\left(10^{-2} \mathrm{~mol} / \mathrm{L}\right)$ was mixed with two fold molar excess lactose and the $\mathrm{pH}$ adjusted to 9.0 by addition of $\mathrm{NaOH}$ [34]. The precursor complex, $\left[\mathrm{Co}(\mathrm{phen})_{2} \mathrm{Cl}_{2}\right] \mathrm{Cl} \cdot 3 \mathrm{H}_{2} \mathrm{O}(3)$ was prepared with a method reported by Ablov [35].

The complexes were separated by chromatography on a Sephadex C25 column and were eluted with $0.1 \mathrm{~mol} / \mathrm{L} \mathrm{NaCl}$.

The eluate was evaporated to dryness under reduced pressure, followed by extraction with ethanol and methanol, to remove the $\mathrm{NaCl}$. Anal. Calcd for $\mathrm{CoC}_{36} \mathrm{H}_{43} \mathrm{~N}_{4} \mathrm{O}_{14} \mathrm{Cl}_{2}$ : Co, 6.66; C, 48.82; H, 4.86; N, 6.33, Found: Co, 7.15; C, 48.32; H, 4.69; N, 5.87.

\subsection{Antimicrobial activity measurements}

All the antimicrobial activity assays were performed in triplicate and confirmed by three separate experiments. The antimicrobial activity was investigated against some Gram-positive (Enterococcus faecalis ATCC29212, Bacillus cereus GCA234 and Staphylococcus aureus ATCC25923) and Gramnegative bacteria (Escherichia coli ATCC25922, Escherichia coli DH5a, Salmonella enterica subsp. enterica serotype Enteritidis ISP/953, Klebsiella pneumoniae RyC492).

Bacteria were grown in Müeller Hinton agar (Difco), as well as Müeller Hinton broth (Difco) for 24 to $48 \mathrm{~h}$ at $37^{\circ} \mathrm{C}$ in an incubator.

The in vitro antibacterial activity of the complexes was tested through paper disc-diffusion method [36], and the minimal inhibitory concentrations (MICs) were determined as the lowest concentrations of drug that inhibits visible bacterial growth [37]. 
2.4 Antibacterial effect

The in vitro antibacterial effect of the complexes was tested using a modified chromogenic plate test assay [38]. E. coli HB101, which contains a chromosomal IPTG-inducible $\beta$-galactosidase gene, was used for this purpose.

The chromogenic agar plates were prepared as follows: first, an inoculum with the strain was grown overnight in $2 \mathrm{~mL}$ of Mueller Hinton media, at $37{ }^{\circ} \mathrm{C}$ with shaking. Then, a top agar-incubation mix of $5 \mathrm{~mL}$ of $0.8 \%$ agar previously melted at $45^{\circ} \mathrm{C}$ containing $0.1 \mathrm{~mL}$ of the bacterial cell inoculum, $0.01 \mathrm{~mL}$ of $1 \mathrm{mmol} / \mathrm{L} \mathrm{IPTG}$, and $0.1 \mathrm{~mL}$ of X-Gal $50 \mathrm{mg} / \mathrm{mL}$ was vortex-mixed and carefully overlaid on Müeller Hinton agar plates prepared the day before. Discs containing the appropriate concentration of complex (1), complex (2) or antibiotic (ceftizoxime and chloramphenicol) were deposited on the chromogenic agar plates. The plates were then incubated at $37^{\circ} \mathrm{C}$ for $12-24 \mathrm{~h}$. Later, the inhibition zones were visually inspected for color formation along de edges of the discs, and plates were photographed. Only compounds causing cellular lysis, can produce a blue-colored edge at the inhibition zone.

\subsection{Growth inhibition test of $E$. coli mutant}

To determine the proteins involved in the uptake of complexes into bacteria, growth inhibition plate assays on $E$. coli K12 mutant strain for outer membrane siderophores receptors $(f h u \mathrm{~A}, f e p \mathrm{~A}, f i u$ and $c i r)$, lactose permease gene $(l a c \mathrm{Y})$ and genes of translocator system $(\operatorname{ton} \mathrm{B}, e x b \mathrm{~B}$ and $e x b \mathrm{D})$ were performed in triplicate and confirmed by three separate experiments. Briefly, an inoculum with $E$. coli $\mathrm{K} 12$ mutant strains (HB101, P8, IR20, H1598, VR42, BR158, HE1 or CH03) were grown overnight in $2 \mathrm{~mL}$ of Müeller Hinton broth, at $37^{\circ} \mathrm{C}$ with shaking. Then, a top agar incubation mix containing $5 \mathrm{~mL}$ of $0.8 \%$ agar previously melted at $45^{\circ} \mathrm{C}$ and $0.1 \mathrm{~mL}$ of the bacterial cell inoculum was vortex-mixed and carefully overlaid on Müeller Hinton agar plates prepared the day before. The discs containing $300 \mu \mathrm{g}$ of complexes (1), (2) or (3) were deposited on the agar plates, which were then incubated at $37^{\circ} \mathrm{C}$ for $12-24 \mathrm{~h}$, after which the inhibition zones were visually inspected and measured.

\subsection{Cytotoxic effect}

The cytotoxicity of complexes was tested in vitro on human cells using microplate cultures of human kidney embryonic cells (HEK293 cells), grown in DMEM medium plus $10 \%$ bovine fetal serum. The number of dead cells was determined by MTT cell proliferation assay after a $24 \mathrm{~h}$ incubation period [39]. This method is a colorimetric assay system that measures the reduction of a tetrazolium component (MTT) into an insoluble formazan product by the mitochondria of viable cells.

The amount of color produced is directly proportional to the number of viable cells. The HEK293 cell line was obtained from Dr. Eduardo Karahanian (Biomedical Research Institute, Universidad Autónoma de Chile).

\section{RESULTS AND DISCUSSION}

3.1 Spectroscopic characterization of $\left[\mathrm{Co}(\text { phen })_{2}\right.$ lactose $] \mathrm{Cl}_{2} \cdot 3 \mathrm{H}_{2} \mathrm{O}(\mathbf{1})$

The IR spectrum of (1) showed the characteristic bands of the 1,10-phenanthroline and maltose ligands. The spectrum shows a broad absorption band at $3352 \mathrm{~cm}^{-1}$ that can be associated with $v(\mathrm{O}-\mathrm{H})$ of lactose, and weak bands at 2990 and $2901 \mathrm{~cm}^{-1}$ that can be assigned to C-H stretching vibrations of lactose and phenanthroline, respectively. At the 1584-1428 $\mathrm{cm}^{-1}$ region the spectrum shows bands corresponding to $v(\mathrm{C}=\mathrm{C}, \mathrm{C}=\mathrm{N})$ of the phenanthroline ligand. Bands between $1377-1315 \mathrm{~cm}^{-1}$ involve $\mathrm{O}-\mathrm{H}, \mathrm{CH}$, and $\mathrm{CH}_{2}$ bending modes of lactose. The band at $1156 \mathrm{~cm}^{-1}$ has been assigned to the C-C in-plane bending, and the bands at 1016 and $1003 \mathrm{~cm}^{-1}$ have been identified as bands associated with the $\mathrm{C}-\mathrm{O}-\mathrm{C}$ bending. The $v \mathrm{H}$ (in-plane) and $\delta \mathrm{H}$ (out-plane) vibration of phenanthroline are located in the $890-668 \mathrm{~cm}^{-1}$ region.

In the ${ }^{1} \mathrm{H}-\mathrm{NMR}$ spectrum of the complex (1), we found two groups of wellseparated signals. At the 7.1- 9.2 ppm region, signals from aromatic hydrogens of the phenanthroline and at 3.2-5.2 ppm region the lactose signals were found. Both signals are in a 1:2 ratio, which agrees with the proposed structure of the complex.

At the anomeric region, the signals belonging to the $\mathrm{H}-1$ of $\alpha$-glucose $\left(5.12 \mathrm{ppm}, \mathrm{J}_{12}=3.6 \mathrm{~Hz}\right)$, the $\mathrm{H}-1$ of $\beta$-glucose $\left(4.56 \mathrm{ppm}, \mathrm{J}_{12}=7.9 \mathrm{~Hz}\right)$ and the $\mathrm{H}-1$ of $\beta$-galactose ( $4.56 \mathrm{ppm}, \mathrm{J}_{1.2}=7.9 \mathrm{~Hz}$ ) can be distinguished (Table 1).

At the 3.2-3.8 ppm region there are overlapping signals and a triplet of the $\mathrm{H}$ bonded to the non-anomeric carbons of the lactose.
Table 1: ${ }^{1} \mathrm{H}$ chemical shifts $(\delta, \mathrm{ppm})$ and coupling constant $\mathrm{J}_{12}(\mathrm{~Hz})$ of $\left[\mathrm{Co}(\text { phen })_{2} \text { lactose }\right]^{2+}$ complex (1) and lactose in $\mathrm{D}_{2} \mathrm{O}$.

\begin{tabular}{|l|c|c|c|}
\hline \multicolumn{1}{|c|}{$\delta, \mathbf{p p m}$} & $\mathrm{H}-1(\beta$-gal $)$ & $\mathrm{H}-1(\alpha$-glu $)$ & H-1 $(\beta$-glu $)$ \\
\hline Complex $(\mathbf{1})$ & 4.35 & 5.12 & 4.56 \\
\hline Lactose & 4.34 & 5.11 & 4.55 \\
\hline $\mathbf{J}_{\mathbf{1}, 2}(\mathbf{H z})$ & & & \\
\hline Complex $(\mathbf{1})$ & 7.8 & 3.6 & 7.9 \\
\hline Lactose & 7.7 & 3.6 & 8 \\
\hline
\end{tabular}

gal = galactose glu $=$ glucose

An absorption band at $271 \mathrm{~nm}$ is seen in the UV spectrum of (1) (Fig 1). The band is associated with $\mathrm{p}$ transitions of the 1,10-phenanthroline ligands. In this region, the $\mathrm{CD}$ spectrum presents two bands of opposite sign, which appears at $267(+)$ and $281(-) \mathrm{nm}$. The sign sequence is related to the $\Delta$ configuration of the chelate rings (excitonic effect) [40].

The complex showed a second positive CD signal as a shoulder in the UV region (295 nm), related to the $\pi \rightarrow \pi^{*}$ transition along the short axis of phenanthroline rings.

In the visible region, complex (1) exhibited an absorption band at $523 \mathrm{~nm}$ corresponding to the ${ }^{1} \mathrm{~A}_{1 \mathrm{~g}} \rightarrow{ }^{1} \mathrm{~T}_{1 \mathrm{~g}}$ transition. In the $\mathrm{CD}$ spectra, two signals (+) and (-) can be detected, which are correlated with the $\Delta$ configuration [41]. The CD spectra also showed a third signal (-) at $360 \mathrm{~nm}$ than can be assigned to the ${ }^{1} \mathrm{~T}_{2 \mathrm{~g}}$ state in octahedral symmetry.

The UV-VIS absorption and CD spectra of (1) are consistent with those reported earlier for $\left[\mathrm{Co}(\text { phen })_{2} \mathrm{~L}\right] \mathrm{Cl}_{2}$, where $\mathrm{L}=$ sucrose or maltose $[42,43]$.
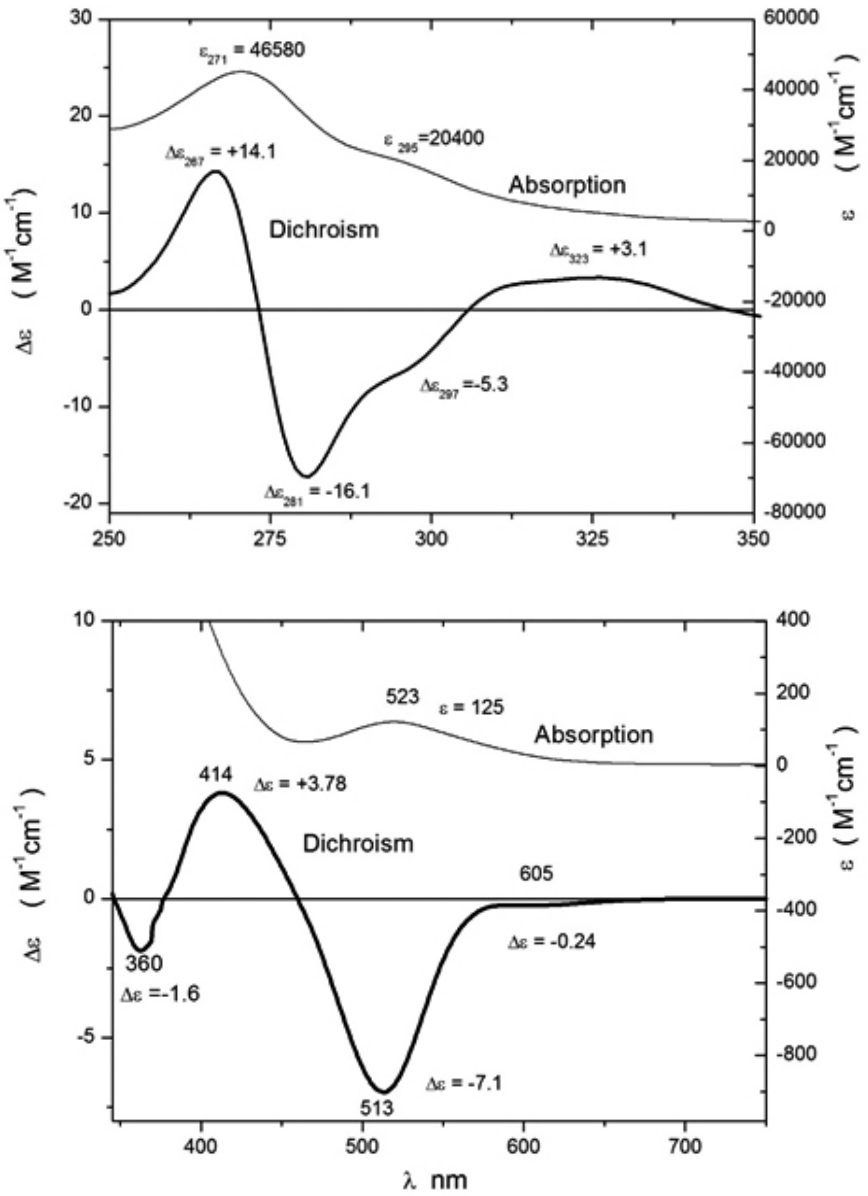

Figure 1: Absorption and circular dichroism (CD) spectra of $\left[\mathrm{Co}(\text { phen })_{2} \text { lactose }\right]^{2+}$ complex (1). 
3.2. Antimicrobial activity of the three cobalt complexes

The in vitro antibacterial activity of complexes (1), (2) and (3) was evaluated against representative Gram-positive and Gram-negative bacteria. Discs with ceftizoxime (ZOX) were used as a control. The results of antibacterial activity and minimum inhibitory concentration (MIC) are reported in Tables 2 and 3, respectively.

The results of this study revealed that (1) and (2) were active against al tested bacteria with minimum inhibitory concentration ranging from 40-70 $\mu \mathrm{g} /$ $\mathrm{mL}$ and $50-80 \mu \mathrm{g} / \mathrm{mL}$ respectively, while complex (3) was active against Gramnegative organisms with minimum inhibitory concentration ranging from $40-$
$80 \mu \mathrm{g} / \mathrm{mL}$, and inactive against the Gram-positive bacteria, showing moderate activity against Staphylococcus aureus.

The three complexes showed less antibacterial activity than ceftizoxime (ZOX), but, surprisingly, both complexes (1) and (2) exhibited antibacteria activity against Enterococcus faecalis and Bacillus cereus, bacteria which are resistant to ceftizoxime.

Disc-diffusion assays showed a similar antibacterial activity of (1) and (3) against Gram-negative bacteria (Table 2), as shown by the MIC's results presented in Table 3 .

Table 2. Qualitative antibacterial activity of the tested complexes.

\begin{tabular}{|c|c|c|c|c|}
\hline \multirow[b]{2}{*}{ Bacteria } & \multicolumn{4}{|c|}{ Growth inhibition zone $(\mathrm{mm}) *$} \\
\hline & $\underset{\text { (1) }}{\left[\mathrm{Co}(\text { phen })_{2} \text { lactose }\right]^{2+}}$ & $\begin{array}{c}\left.[\text { Co(phen })_{2} \text { sucrose }\right]^{2+} \\
(2)\end{array}$ & $\underset{\text { (3) }}{\left[\mathrm{Co}(\text { phen })_{2} \mathrm{Cl}_{2}\right]^{+}}$ & ZOX \\
\hline $\begin{array}{l}\text { Escherichia coli } \text { ATCC25922 } \\
\text { Escherichia coli } \mathrm{DH} 5 \alpha \\
\text { Salmonella Enteritidis } \text { ISP/953 } \\
\text { Klebsiella pneumoniae } \text { RyC492 }\end{array}$ & $\begin{array}{l}18.0 \pm 0.1 \\
18.2 \pm 0.8 \\
14.3 \pm 0.2 \\
14.7 \pm 0.2\end{array}$ & $\begin{array}{c}9.3 \pm 0.6 \\
8.7 \pm 0.6 \\
14.5 \pm 0.9 \\
11.5 \pm 1.0\end{array}$ & $\begin{array}{l}19.8 \pm 0.8 \\
19.5 \pm 0.5 \\
10.3 \pm 1.5 \\
15.0 \pm 0.1\end{array}$ & $\begin{array}{l}31.0 \pm 0.4 \\
31.0 \pm 0.5 \\
32.0 \pm 0.6 \\
31.0 \pm 0.5\end{array}$ \\
\hline $\begin{array}{l}\text { Enterococcus faecalis ATCC29212 } \\
\text { Bacillus cereus GCA234 } \\
\text { Staphylococcus aureus ATCC25923 }\end{array}$ & $\begin{array}{l}12.2 \pm 0.5 \\
14.8 \pm 0.9 \\
11.3 \pm 0.9\end{array}$ & $\begin{array}{c}9.2 \pm 0.6 \\
14.4 \pm 0.3 \\
12.8 \pm 0.5\end{array}$ & $\begin{array}{c}\mathrm{R} \\
\mathrm{R} \\
7.3 \pm 0.6\end{array}$ & $\begin{array}{c}\mathrm{R} \\
\mathrm{R} \\
34.1 \pm 0.7\end{array}$ \\
\hline
\end{tabular}

* Material used: disc with $300 \mu \mathrm{g}$ of compound. Number of assays $=3$. ZOX: ceftizoxime (disc with $30 \mu \mathrm{g}$ ). $\mathrm{R}$ is resistant

Table 3. Minimum inhibitory concentration (MIC) of complexes tested.

\begin{tabular}{|c|c|c|c|}
\hline \multirow[b]{2}{*}{ Bacteria } & \multicolumn{3}{|c|}{ MIC $(\mu \mathrm{g} / \mathrm{mL}) *$} \\
\hline & $\underset{(1)}{\left[\mathrm{Co}(\text { phen })_{2} \text { lactose }\right]^{2+}}$ & $\begin{array}{c}{\left[\mathrm{Co}(\text { phen })_{2} \text { sucrose }\right]^{2+}} \\
(2)\end{array}$ & $\begin{array}{c}\left.[\mathrm{Co} \text { (phen) })_{2} \mathrm{Cl}_{2}\right]^{+} \\
\text {(3) }\end{array}$ \\
\hline Escherichia coli $\mathrm{ATCC} 25922$ & 40 & 80 & 40 \\
\hline Salmonella Enteritidis ISP/953 & 50 & 50 & 80 \\
\hline Klebsiella pneumonia RyC492 & 50 & 60 & 50 \\
\hline Enterococcus faecalis ATCC 29212 & 70 & 80 & $>500$ \\
\hline Bacillus cereus GCA234 & 50 & 50 & $>500$ \\
\hline Staphylococcus aureus ATCC25923 & 60 & 60 & 90 \\
\hline
\end{tabular}

$*$ Number of assays $=3$.

A cobalt (III) complex reported by Arunachalam et al. cis$\left[\mathrm{Co}(\text { phen })_{2}\left(\mathrm{C}_{14} \mathrm{H}_{29} \mathrm{NH} \mathrm{H}_{2}\right) \mathrm{Cl}\right]\left(\mathrm{ClO}_{4}\right)_{2} \cdot 3 \mathrm{H}_{2} \mathrm{O}$ has a similar antibacterial activity against $S$. aureus, Bacillus subtilis, and $E$. coli, with growth inhibition zones in a range of $15-11 \mathrm{~mm}$. The authors indicate that the high antibacterial activity can be related to the hydrophobic character of the compound [44].

Another example is the cobalt (III) complex with 2,2-bipyridine [Co(PZAH) (bipy) $)_{2}\left(\mathrm{ClO}_{4}\right)_{2}$, where $\mathrm{PZAH}_{2}=$ pyrazinamide, reported by Chiniforoshan et al. [45]. This complex generates growth inhibition zones of 24.5 and $22.3 \mathrm{~mm}$ of diameter against Bacillus and E. coli respectively.

Moreover, cobalt (II) complexes with antibacterial activity and MIC values similar to those of complex (1) have been reported. For example, $\left[\mathrm{Co}(\mathrm{valp})_{2}\right.$ (phen) $\left.\mathrm{H}_{2} \mathrm{O}\right]$ complex $(\mathrm{Valp}=$ sodium valproate, phen= 1,10-phenanthroline) has MIC values of $50 \mu \mathrm{g} / \mathrm{mL}$ and $30 \mu \mathrm{g} / \mathrm{mL}$ against $S$. aureus and E. coli respectively [7].

3.3 Antibacterial-action mode and uptake mechanism of the three cobalt complexes.

To distinguish the antimicrobial-action mode of the complexes studied, a colorimetric plate assay method was used [46, 47], with $\beta$-galactosidase chosen as an appropriate marker of cellular lysis. If lysis occurs, the enzyme is released outside the bacterium and detected on the plate.

When the enzyme reaches the agar medium, it hydrolyzes 5-bromo-4- chloro-3-indolyl- $\beta$-D-galactoside (X-Gal), a chromogenic compound included in the agar. After overnight incubation, X-Gal forms a blue circle staining the edge of the inhibition zone produced by the antibiotic application. It is perhaps pertinent to emphasize that only those compounds causing cellular lysis or membrane damage do produce a blue-colored edge at the inhibition zone (bactericide effect).

The assay showed that (1), (2) and (3) present bacteriostatic activity against bacterial cells since they do not produce a blue circle staining the edge of the inhibition zone (Fig. 2). In these assays, ceftizoxime and chloramphenicol were used as bactericidal and bacteriostatic control agents, respectively. The results indicate that the three complexes studied have their target on the inside of the bacterial cell.

Considering that (1), (2), and (3) have a bacteriostatic effect on the bacterial cell, two possible routes for internalization or uptake of complexes were explored. The first one implies a specific sugar receptor for carbohydrate transport into E. coli, lacY protein [48]. The second route analyzed corresponds to a siderophore uptake pathway, that includes an outer-membrane receptor and translocation system TonB (TonB/ ExbB/ExbD proteins) [49]. For these assays, E. coli mutated for lacY protein and siderophore receptors were used.

From the results in Table 3, it can be seen that the activity of complex (1) on E. coli HB101 (lacY mutant) decreases slightly as compared with the 
activity it presents against $E$. coli $\mathrm{DH} 5 \alpha$. The growth inhibition zone reduces from 18.2 to $16.8 \mathrm{~mm}$. On the other hand, complexes (2) and (3) maintain their antibacterial activity. These results suggest that (1) presents further internalization routes to the bacterium in addition to lacY. Complexes (2) and (3), instead, do not use this route of entry.

When the activity of $E$. coli strains with mutated genes for siderophore receptors (P8, IR20, H1598, VR42) are analyzed, the results show that the antibacterial activity of complexes (1) and (3) decreases markedly as compared to the activity against $E$. coli $\mathrm{DH} 5 \alpha$, used as a control. This could indicate that complexes (1) and (3) might use as the main gateway to the bacteria the outer- membrane proteins FhuA, FepA, Cir and Fiu. In the case of complex (2), no change is observed in the activity against the mutated bacteria, suggesting that this complex uses different routes to enter into the bacteria.

A similar situation occurs when using mutated $E$ coli in the translocation system (BR158, HE1, and CH03). Complexes (1) and (3) present a decreased antibacterial activity unlike complex (2) which maintains it unaltered. These results indicate that complexes (1) and (3) use the translocation system TonB / ExbB / EXBD, in order to cross from the periplasm to the cytoplasm of the cell. Complex (2) instead would use a different route of entry.

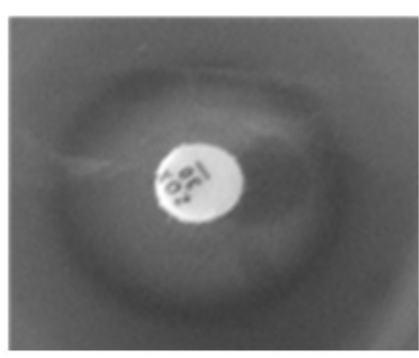

Ceftizoxime (bactericide agent)

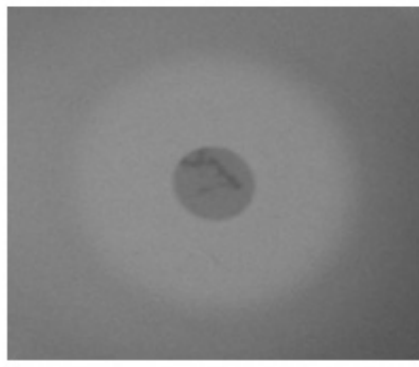

$\operatorname{Co}(\text { phen })_{2}$ Lactose $^{2+}$

(1)

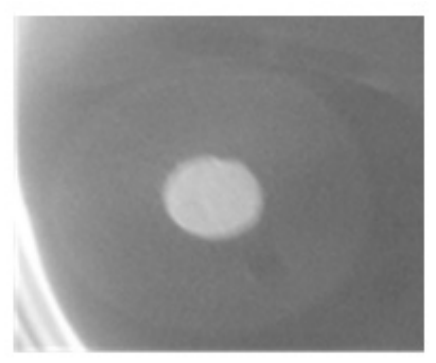

Chloramphenicol (bacteriostatic agent)

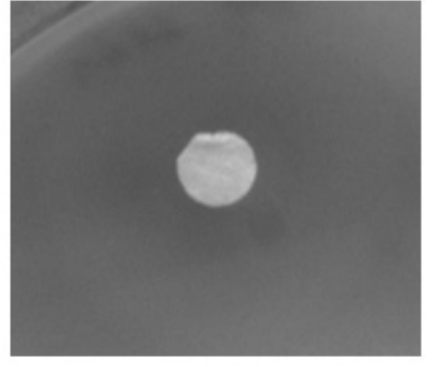

$\left[\mathrm{Co}(\text { phen })_{2} \text { Sucrose }\right]^{2+}$

(2)

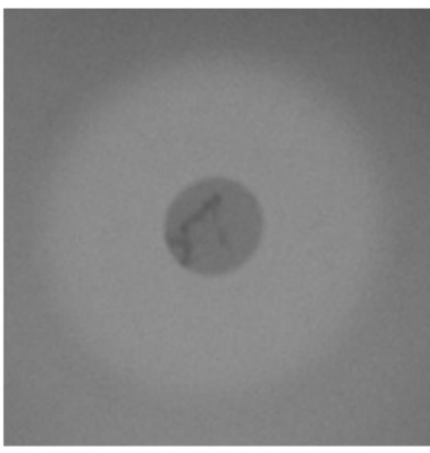

$\left[\mathrm{Co}(\text { phen })_{2} \mathrm{Cl}_{2}\right]^{+}$

(3)

Figure 2. Plate assay showing a bacteriostatic or bacteriolytic effect for complexes (1), (2) and (3) against Gram-negative bacterium Escherichia coli HB101. Materials used in the assay: a disc with $400 \mu \mathrm{g}$ of the analyzed complex, and discs of ceftizoxime $(30 \mu \mathrm{g} / \mathrm{disc})$ and chloramphenicol $(30 \mu \mathrm{g} / \mathrm{disc})$, which were used as bacteriostatic and bacteriolytic control respectively. 
Table 4. Growth inhibition test of mutant $E$. coli strains by complexes tested.

\begin{tabular}{|c|c|c|c|c|c|}
\hline \multirow[b]{2}{*}{$\begin{array}{l}E . \text { coli } \\
\text { strain }\end{array}$} & \multirow[b]{2}{*}{ Mutated gene } & \multirow[b]{2}{*}{ Function of mutated protein } & \multicolumn{3}{|c|}{ Growth inhibition zone $(\mathrm{mm}) *$} \\
\hline & & & {$\left[\begin{array}{c}{\left[\mathrm{Co}(\text { phen })_{2} \text { lactose }\right]^{2+}} \\
\text { (1) }\end{array}\right.$} & {$\left[\mathrm{Co}(\text { phen })_{2} \text { sucrose }\right]^{2+}$} & $\underset{\text { (3) }}{\left[\mathrm{Co}(\text { phen })_{2} \mathrm{Cl}_{2}\right]^{+}}$ \\
\hline DH5 $\alpha$ & - & - & $18.2 \pm 0.8$ & $8.7 \pm 0.6$ & $19.5 \pm 0.5$ \\
\hline HB101 & $l a c \mathrm{Y}$ & Lactose importer & $16.8 \pm 0.3$ & $8.7 \pm 0.6$ & $19.2 \pm 0.8$ \\
\hline P8 & fhuA & Siderophore out membrane receptor & $6.0 \pm 0.1$ & $8.2 \pm 0.9$ & $6.0 \pm 0.1$ \\
\hline IR20 & fepA & Siderophore out membrane receptor & $6.0 \pm 0.1$ & $7.7 \pm 0.1$ & $6.0 \pm 0.1$ \\
\hline H1598 & $f i u$ & Siderophore out membrane receptor & $6.0 \pm 0.1$ & $8.7 \pm 0.1$ & $6.0 \pm 0.1$ \\
\hline VR42 & $\operatorname{cirA}$ & Siderophore out membrane receptor & $6.0 \pm 0.1$ & $8.5 \pm 0.1$ & $6.0 \pm 0.1$ \\
\hline BR158 & ton $\mathrm{B}$ & Principal component of inner membrane uptake & $6.0 \pm 0.1$ & $8.5 \pm 0.3$ & $6.0 \pm 0.1$ \\
\hline HE1 & $\operatorname{exbB}$ & Accessory component of TonB system & $6.0 \pm 0.1$ & $9.1 \pm 0.1$ & $6.0 \pm 0.1$ \\
\hline
\end{tabular}

*Number of assays $=3$.

A

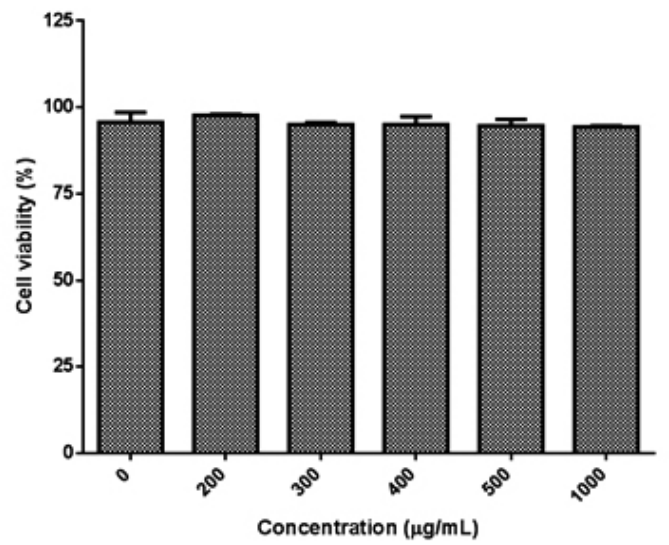

C
B

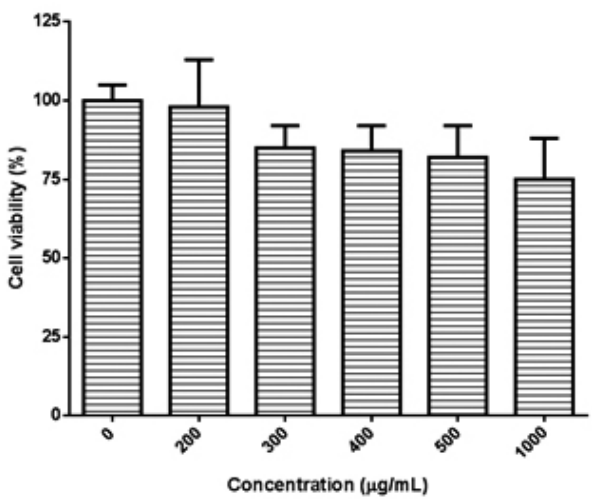

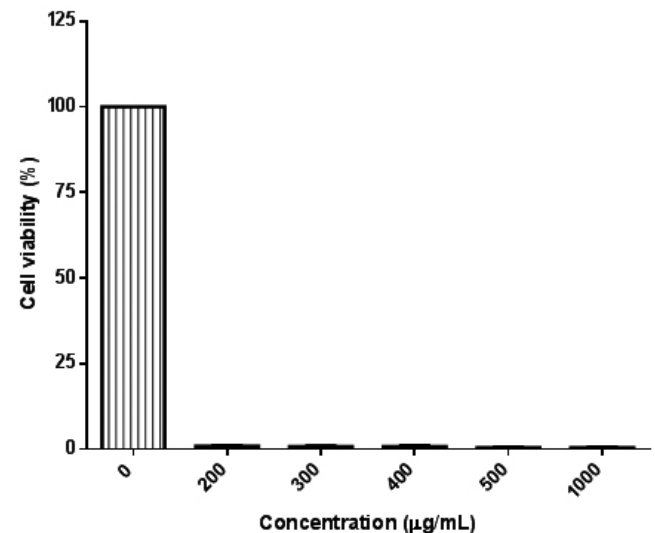

Figure 3. The in vitro cytotoxicity effect of complexes (1), (2) and (3) against human cell (HEK293 cell). The graphic A (gray bar), corresponds to cell viability of a HEK293 cell line incubated with [Co(phen) $)_{2}$ lactose ${ }^{2+}$ (1) during 24 h. The graphic $\mathrm{B}$ (white bar with horizontal lines), corresponds to cell viability of a HEK293 cell line incubated with $\left[\mathrm{Co}(\mathrm{phen})_{2} \mathrm{sacarose}\right]^{2+}$ (2), during $24 \mathrm{~h}$. The graphic $\mathrm{C}$ (white bar with vertical lines), corresponds to cell viability of a HEK293 cell line incubated with $\left[\mathrm{Co}(\mathrm{phen})_{2} \mathrm{Cl}_{2}\right]^{+}(3)$ during $24 \mathrm{~h}$. Non-statistical differences were detected $(\mathrm{p}>0.05)$ for graphics A and $\mathrm{B}$, while statistical differences were detected $(\mathrm{p}<0.05)$ for graphic $\mathrm{C}$. 
3.4 Cytotoxicity effect against human cell

In order to evaluate the ability of compounds to damage eukaryotic cells, the in vitro cytotoxic effect of these complexes was tested with human kidney embryonic cells (HEK293 cell) (Fig. 3).

The data obtained from the MTT assay showed that complex (1) is not toxic to human cells in the tested concentrations range. Similarly, complex (2) did not show cytotoxicity in human cells (no statistical differences were detected $(\mathrm{p}>0.05)$ in the range of tested concentrations).

In contrast, the complex (3) is cytotoxic in all the range of studied concentrations (Fig. 3C).

These results suggest that the presence of carbohydrates as ligands in the complexes reduces cytotoxicity against human kidney embryonic cells, which is consistent with the results previously obtained for complexes with maltose or arabinose [43].

It is worth noting that when the cytotoxicity of new compounds is evaluated, the corresponding studies are usually performed on tumor cell lines. Since the final aim of this research is to find compounds to inhibit growth or even destroy the bacteria with no harm to healthy cells, the alternative of using ligands or complexes with little or no cytotoxicity on eukaryotic cells is interesting.

\section{CONCLUSIONS}

We synthesized a new cobalt (III) complex with phenanthroline and lactose (1). Based on its optical properties, a formula [ $\mathrm{Co}(\text { phen) })_{2}$ lactose $] \mathrm{Cl}_{2} \cdot 3 \mathrm{H}_{2} \mathrm{O}$ and an absolute delta configuration have been assigned to the complex (1).

The in vitro assays showed that the complexes (1), (2) and (3) exhibited moderate antibacterial activity, with bacteriostatic effect over the studied bacteria.

The presence of carbohydrate ligands in the complexes (1) and (2) improves the antibacterial properties over Gram positive in contrast with complex (3).

Assays using mutant E. coli strains demonstrate that TonB-dependent siderophore uptake system is involved in uptake and transport of the complexes (1) and (3) into the bacterial cell.

Furthermore, the MTT assays using human cell treated with complexes (1), (2) and (3) showed that the presence of carbohydrate ligands decreases the cytotoxic effect over the eukaryotic cell of the metal complexes tested.

\section{REFERENCES}

1.- $\quad$ B. S. Sekhon, J. Pharm. Educ. Res. 2, 1, (2011)

2.- A. K. Ghosh, M. Mitra, A Fathima, H. Yadav, A.R. Choudhury, B.U. Nair, R. Ghosh, Polyhedron 107, 1, (2016)

3.- K. Alomar, A. Landreau, M. Allain, G. Bouet, G. Larcher, J. Inorg. Biochem. 126, 76, (2013)

4.- K. D. Mjos and C. Orvig, Chem. Rev. 114, 4540, (2014)

5.- S. V. Kumar, S. Scottwell, E. Waugh, C. J. McAdam, L. R. Hanton, H. J. L. Brooks, J. D. Crowley, Inorg. Chem. 55, 9767, (2016)

6.- $\quad$ M. Salehi, M. Hasanzadeh, Inorg. Chim. Acta 426, 6, (2015)

7.- $\quad$ L. Tabrizi, P. McArdle, M. Ektefan, H. Chiniforoshan, Inorg. Chim. Acta 439, 138, (2016)

8.- M. Salehi, M. Amirnasr, S. Meghdadi, K. Mereiter, H.R. Bijanzadeh, A. Khaleghian, Polyhedron 81, 90, (2014)

9.- P. Fernandes, I. Sousa, L. Cunha-Silva, M. Ferreira, B. de Castro, E.F. Pereira, M.J. Feio, P. Gameiro, J. Inorg. Biochem. 131, 21, (2014)

10.- D.U. Miodragovic, G.A. Bogdanovic, Z.M. Miodragovic, M.D. Radulovic, S.B. Novakovic, G.N. Kaludjerovic, H. Kozlowski, J. Inorg. Biochem. 100, 1568, (2006)

11.- K. Nomiya, A. Yoshizawa, K. Tsukagoshi, N.C. Kasuga, S. Hirakawa, J. Watanabe. J. Inorg. Biochem. 98, 46, (2004)

12.- D. Bandyopadhyay, M. Layek, M. Fleck, R. Saha, C. Rizzoli, Inorg. Chim. Acta 461, 174, (2017)

13.- H. Keypour, M. Mahmoudabadi, A. Shooshtari, M. Bayat, M. Ghassemzadeh, L. Hosseinzadeh, F. Mohsenzadeh, K. Harms, Polyhedron 129, 189, (2017)

14.- R. Sethi, M. Ahuja, Int. Pharm. Tech. Res. 9 (1), 35, (2016)

15.- C. X. Zhang, S.J. Lippard, Curr. Opin. Chem. Biol. 7, 481, (2003)

16.- T.W. Failes, T.W. Hambley, Dalton Trans. 1895, (2006)

17.- B. Coyle, K. Kavanagh, M. McCann, M. Devereux, M. Geraghty, Biometals. 16, 321, (2003)

18.- H. Gopinathan, N. Komathi, M.N. Arumugham, Inorg. Chim. Acta 416, 93, (2014)
19.- P. Heffeter, M.A. Jakupec, W. Körner, S. Wild, N.G. von Keyserlingk, L.Elbing, H. Zorbas, A. Korynevska, S. Knasumüller, H. Sutterlüty, M. Micksche, B.K. Keppler, W. Berger, Biochem. Pharm. 71, 426, (2006)

20.- P. Gameiro, C. Rodrigues, T. Baptista, I. Sousa, B. de Castro, Int. J. Pharm. 334, 129, (2007)

21.- A. T. Colak, P. Oztopcu-Vatan, F. Colak, D. Akduman, S. Kabadere, R. Uyar, J. Trace Elem. Med. Biol. 27, 295, (2013)

22.- M. A. Zoroddu, S. Zanetti, R. Pogni, R, Basosi, J. Inorg. Biochem. 63 (4), 291, (1996)

23.- S. S. Hindo, M. Frezza, D. Tomco, M. J. Heeg, L. Hryhorczuk, B. R. McGarvey, Q. P. Dou, C.N. Verani, Eur. J. Med. Chem. 44, 4353, (2009)

24.- P. F. Liguori, A. Valentini, M. Palma, A. Bellusci, M. Palma, A. Bellusci, S. Bernardini M. Ghedini, M. L. Panno, C. Pettinari, F. Marchetti, A. Crispini, D. Pucci, Dalton Trans. 39, 4205, (2010)

25.- M. Geraghty, V. Sheridan, M. McCann, M. Devereux, V. McKee, Polyhedron 18, 2931, (1999)

26.- L.R McDowell,Vitamins in Animal and Human Nutrition. Iowa State University Press, Ames, 2000

27.- G.T Taylor, C.W. Sullivan, Limnol. Oceanogr. 53 (5), 1862, (2008)

28.- J. M. Pratt, Inorganic chemistry of vitamin B12. Academic Press, New York, 1972

29.- E. C. Hatchikian, Biochem. Biophys. Res. Commun. 103, 521, (1981)

30.- E.L. Chang, C. Simmers, D. A.Knight, Pharmaceuticals 3, 1711, (2010)

31.- R. S. Kumar, P. Paul, A. Riyasdeen, G. Wagniéres, H. van den Bergh, M. A. Akbarsha, S. Arunachalam, Colloids and Surfaces B: Biointerfaces, 86, 35, (2011)

32.- B. Zarranz, A. Jaso, I. Aldana, A. Monge, Bioorg. Med. Chem. 11, 2149, (2003)

33.- J. J. Irbaraj, A.G. Motten, C.F. Chignell, Chem. Res. Toxicol. 16, 164, (2003)

34.- a) J. Parada, S. Bunel, C. Ibarra, G. Larrazábal, E. Moraga, Carbohydr. Res. 329, 195, (2000). b) J. Parada, G. Larrazábal, Polyhedron 23, 1341, (2004)

35.- A.V. Ablov, Russ. J. Inorg. Chem. 6, 157, (1961)

36.- K. L. Kwaniewska, Bull. Environ. Contam. Toxicol. 27, 289, (1981)

37.- National Committee for Clinical Laboratory Standards: Methods for Dilution. Antimicrobial Susceptibility Tests for Bacteria That Grow Aerobically, Fifth Edition: Approved Standard M7-A5. NCCLS, Wayne, PA, USA, 2000.

38.- G. Mardones, A. Venegas, J. Microbiol. Meth. 40, 199, (2000)

39.- S. Maher, M. McClean, Biochem. Pharmacol. 71, 1289, (2006)

40.- a) C. J. Hawkins, Absolute Configuration of Metal Complexes, Wiley, New York, 1971.

b) K. Nakanishi, N. R. W. Berova, Woody (Eds.), Circular Dichroism, Principles and Applications, VCH, Cambridge, 1994.

41.- I. Tinoco, Adv. Chem. Phys. 4, 113, (1962). b) F.S. Richardson, J. Chem. Phys. 54, 2453, (1971)

42.- J. Parada, S. Bunel, C. Ibarra, G. Larrazábal, E. Moraga, N.G. Gillitt, C A. Bunton, Carbohydr. Res. 333, 185, (2001)

43.- J. Parada, A.M. Atria, G. Weiss, E. Rivas, G. Corsini, J. Chil. Chem. Soc. 59, 2636, (2014)

44.- R. S. Kumar, S. Arunachalam, Biophys. Chem. 136, 136, (2008)

45.- H. Chiniforoshan, Z. Sadeghian Radani, L. Tabrizi, H. Tavakol, M. R. Sabzalian, G. Mohammadnezhad, H. Görls, W. Plass, J. Mol. Struct. 1081, 237, (2015)

46.- P. Cortés-Cortés, A.M. Atria, M. Contreras, O. Peña, K. Fernandez, G. Corsini, J. Chil. Chem. Soc. 53, 1527, (2008)

47.- A.M. Atria, P. Cortés-Cortés, M.T. Garland, R. Baggio, K. Morales, M. Soto, G. Corsini, J. Chil. Chem. Soc. 56, 786, (2011)

48.- M. H. Saier, Mol. Microbiol. 35, 699, (2000)

49.- K. Schauer, B. Gouget, M. Carrière, A. Labigne, H. De Reuse, Mol. Microbiol. 63, 1054, (2007). 